\title{
RECUEIL DE RÉFÉRENCES BIBLIOGRAPHIQUES FRANÇAISES CONCERNANT L'ANGUILLE (ANGUILLA ANGUILLA L.) SUR LA PÉRIODE 1987-1994.
}

\author{
C. RIGAUD, C. GARDES, N. CASTOR \\ CEMAGREF de Bordeaux - 33612 CESTAS Cedex (France).
}

\section{RÉSUMÉ}

Pour la période 1987-1994, le recueil non exhaustif des références bibliographiques françaises concernant l'anguille (Anguilla anguilla) a été réalisé en novembre 1994.

Il est constitué :

- pour les publications et thèses, des références obtenues par interrogation des bases ASFA (Partie 1) et PASCAL et par consultation des Current Contents (Agriculture, Biologie, Environnement),

- pour les autres documents, des références signalées au secrétariat du Groupe de travail «Anguille»du GRISAM (GIS Poissons Amphihalins) et de celles obtenues par interrogation de la base documentaire du CEMAGREF de Bordeaux.

\section{COMPILATION OF FRENCH BIBLIOGRAPHICAL REFERENCES ON EEL (ANGUILLA ANGUILLA L.) BETWEEN 1987 AND 1994.}

\section{ABSTRACT}

A non exhaustive compilation of French works on eel (Anguilla anguilla) between 1987 and 1994 was realized in November 1994.

Publications and thesis were obtained by consulting two databases (ASFA Part.1, PASCAL) and the Current Contents (Agriculture, Biology and Environmental Sciences).

The other references (technical reports,...) were obtained by consulting the bibliographic database of CEMAGREF Bordeaux and the listing of the references indicated to the French working group on eel. 


\section{AVANT-PROPOS} faites.

Avant la consultation de cette liste de références, trois remarques méritent d'être

Tout d'abord, étant donné la méthode de recueil utilisée, cette liste ne doit pas être considérée comme exhaustive même si la très grande majorité des documents édités sur la période 1987-1994 y figure très vraisemblablement.

Ensuite, afin de faciliter la consultation, un double classement a été réalisé :

- D'une part, les documents ont été regroupés selon sept thèmes :

- Biologie de l'espece

- PHYSIOLOGIE

- Pathologie et contamination par polluants

- Migrations et Déplacements dans les eaux continentales

- Exploitation halieutioue

- Aquaculture

- Commercialisation

- D'autre part, au sein de chaque thème, un classement par type de document a été effectué :

- Publications

- Rapports techniques

- COMmunications

— Documents universitaires : Theses, Diplomes de Docteurs IngÉnieurs (DDI)

Enfin, malgré l'importance quantitative et qualitative des travaux effectués sur cette période, on doit constater et regretter l'absence de données de dynamique de stock au moins à l'échelle de quelques bassins versants.

La gestion raisonnée de cette espèce européenne, qui devra nécessairement voir le jour dans les années à venir si l'on souhaite pouvoir encore longtemps concilier préservation et exploitation de cette population, aurait pourtant bien besoin de ce type de données. Le groupe de travail "Anguille "le répète sans grand succès depuis 1984. II faut espérer que les années à venir verront une avancée sur ce plan dans le cadre de travaux français et européens. 


\section{BIOLOGIE DE L'ESPECE}

\section{PUBLICATIONS}

1987

VOLLESTAD L.A., LECOMTE-FINIGER R., STEINMETZ B., 1987- Age determination of Anguilla anguilla (L.1758) and related species. EIFAC Occasional Paper 21, 1-28.

1988

SAGLIO P., ESCAFFRE A.M., BLANC J.M., 1988 - Structural characteristics of the epidermal mucosa in yellow and silver European eel (A. anguilla). J. Fish Biol., 32 (4), 505-514.

\section{9}

BRUSLE J., 1989 - Les migrations au cours du cycle biologique des anguilles : de l'aire de ponte marine à la colonisation des milieux continentaux (leptocéphales, civelles et anguilles jaunes). Oceanis, 15 (2), 181-195

BRUSLE J., 1989 - L'anguille européenne Anguilla anguilla, une espèce jugée commune jusqu'à la dernière décennie, mérite-t-elle d'acquérir aujourd'hui le statut d'espèce menacée ? Soc. Zool. France, Perpignan, 114 (3), 61-73.

FONTAINE Y.A., 1989 - Les anguilles : migration et reproduction. Oceanis, 15 (2), 197-206.

LECOMTE R., YAHYAOUI A., 1989 - La microstructure de l'otolithe au service de la connaissance du développement larvaire de l'anguille européenne Anguilla anguilla. CR. Acad. Sci. Paris, 308, 1-7.

LECOMTE R., 1989 - Les apports récents de l'étude des otolithes de téléostéens au MEB : application à l'anguille européenne Anguilla anguilla. Soc. Zool. France, Perpignan, 114 (3), 164-165.

\section{0}

GUERAULT D., DESAUNAY Y., 1990 - The evolution of recruitment of glass eel (Anguilla anguilla) in the Loire estuary (France) from 1977 to 1988. Int. Rev. gesamt. Hydrobiol., 75 (6) (special issue), 717-719.

LECOMTE R., 1990 - Données préliminaires sur la composition chimique des otolithes d'anguilles Anguilla anguilla. Rap. C.I.E.M., 32 (1), $270 p$.

LECOMTE R., 1990 - Métamorphose de l'anguille jaune en anguille argentée Anguilla anguilla et sa migration catadrome. Ann. Biol., 29 (3), 183-194.

LECOMTE-FINIGER R., YAHYAOUI A., 1990 - Otolith microstructure analysis in the knowledge of the early life history of the european eel Anguilla anguilla. Int. Rev. gesamt. Hydrobiol., 75 (6), 861.

LEGAULT A., PORCHER J.P., 1990 - Distribution du peuplement d'anguilles à l'échelle régionale Bretagne et Basse-Normandie (France). Int. Rev. gesamt. Hydrobiol., 75/6, 794.

PANFILI J., XIMENES M.C., DO CHI T., MIRALLES A., 1990 - Age determination of eels in the French mediterranean lagoons using classical methods and an image analysis system. Int. Rev. gesamt. Hydrobiol., 75 (6), 745-754.

1991

ALCOBENDAS M., LECOMTE F., CASTANET J., MEUNIER F.J., MAIRE P., HOLL M., 1991 - Technique de marquage en masse de civelles ( $A$. anguilla) par balnéation rapide dans le fluochrome - Application au marquage à la tétracycline de $500 \mathrm{~kg}$ de civelles. Bull. Fr. Pêche Piscic., 321, 43-54. 
FONTAINE Y.A., DUFOUR S., 1991 - The eels: from life cycle to reproductive endocrinology. Bull. Inst. Zool., Academia Sinica, Monograph, 16, 237-248.

LECOMTE-FINIGER R., 1991 - Microstructure of the larval otolith of the european eel Anguilla anguilla : notes on the early life. Biological structures and morphogenesis (Ed. Masson, Paris), vol 3 (3), 115-128,

LECOMTE-FINIGER R., 1991a - The crystalline ultrastructure of otoliths of the eels (Anguilla anguilla L.). J. Fish Biol., 40, 181-190.

SIMON B., SEBERT P., BARTHELMY L., 1991 - Eel, Anguilla anguilla, muscle modifications induced by long term exposure to 101 ATA hydrostatic pressure. J. Fish Biol., 38 (1), 89-94.

1992

CAILLOU A., FRANCISCO C., LECOMTE-FINIGER R., SALMON J.M., 1992 - Lipofuscin used as an age indicator in the european eel (Anguilla anguilla). Comparison between lipopigment, fluorimetric measurements and otolithometric data. Irish Fish. Invest., Ser. A (Freshwater), 36, 104-107.

ELIE P., 1992 - Histoire d'une vie d'anguille - De l'aire de ponte à l'approche des côtes de l'Europe et d'Afrique. Le Pêcheur Professionnel, 2, 21-22.

ELIE P., 1992 Histoire d'une vie d'anguille - La colonisation des eaux continentales d'Europe et d'Afrique. Le Pêcheur Professionnel 3, 13-15.

FEUNTEUN E., RIGAUD C., ELIE P., LEFEUVRE J.C., 1992 - Le marais doux endigué de Bourgneuf-Machecoul (Pays de Loire) - Premiers éléments de connaissance du peuplement piscicole - Relations ichtyofaune-habitats et problèmes majeurs de gestion. Rev. Sci. Eau, 5 (4), 509-528.

FONTAINE M., 1992 - Les anguilles - Le rôle joué par l'Institut Océanographique de Monaco dans le développement des connaissances sur leur biologie. Bull. Inst. Océanogr., NS 10, V-XXVI.

GUERAULT D., LECOMTE-FINIGER R., DESAUNAY Y., BIAGANTI-RISBOURG S., BEILLOIS P., GRELLIER P., 1992 - Glass eel arrivals in the Vilaine estuary (Northern bay of Biscay) in 1990 - Demographic features and early life history. Irish. Fish. Invest. Ser. A (Freshwater), 36, 5-14.

LECOMTE-FINIGER R., 1992 - Données préliminaires sur la composition chimique des otolithes d'anguille (Anguilla anguilla) - Avancées en océanologie méditerranéenne. Bull. Inst. Océanogr., NS 11, 227-233.

LECOMTE-FINIGER R., 1992 - The crystalline ultrastructure of otoliths of the eel (Anguilla anguilla L. 1758). J. Fish Biol., 40 (2), 181-190.

LECOMTE-FINIGER R., 1992 - Growth history and age at recruitment of European glass eels (Anguilla anguilla) as revealed by otolith microstructure. Marine Biology, 114 (2), 205-210.

LECOMTE-FINIGER R., 1992 - Situation actuelle de l'évaluation de l'age individuel de l'anguille (Anguilla anguilla). in Baglinière $J L$, Castanet $J$, Conand $F$, Meunier FJ, Ed., "Tissus durs et âge individuel des vertébrés", INRA/ORSTOM, Bondy (France), 103-108.

LECOMTE-FINIGER R., BIAGANTI-RISBOURG S., DESAUNAY Y., GUERAULT D., FOURCAULT B., PLANES S., YAHYAOUI A., 1992 - Age at recruitment of Anguilla anguilla glass eels on the eastern Atlantic coast as inferred from otolith growth increments. Irish Fish. Invest., Ser. A (Freshwater), (36), 23-24.

MALLAWA A., LECOMTE-FINIGER R., 1992 - Comparative study of two populations of Anguilla anguilla (L.1758) eels from french mediterranean lagoons (Bages-Sigean et Canet- Saint Nazaire) : age and population structure. Sci. Mar., 56 (1), 1-6. 
MARQUET G., 1992 - L'étude du recrutement et de la physiologie des anguilles de Polynésie Française permet-elle de cerner leur aire de ponte? Bull. Inst. Oceanogr., NS10, 129-147.

PANFILI J., XIMENES M.C., 1992 - Measurements on ground or sectioned otoliths : possibilities of bias. J. Fish Biol., 41 (2), 201-207.

PANFILI J., LOUBENS G., 1992 - Mise en évidence des structures de croissance pour l'estimation de l'âge individuel des poissons - Exemple de Prochilodus nigricans (Prochilodidae, Characiforme) - In : Tissus durs et âge individuel des Vertébrés. Coll. Nationale Bondy, France, 4-6 mars 1991, Baglinière J.L., Castanet J., Conan F., Meunier F.J. (éd.), Coll. et Sémin. ORSTOM-INRA, 335-340.

PANFILI J., XIMENES M.C., CRIVELLI A.J., DO CHI T., 1992 - Validation de l'âge de l'anguille européenne dans les lagunes méditerranéennes françaises (Camargue) : résultats préliminaires. in : Tissus durs et âge individuel des Vertébrés. Coll. Nationale Bondy, France, 4-6 mars 1991, Baglinière J.L., Castanet J., Conan F., Meunier F.J. (éd.), Coll. et Sémin. ORSTOM-INRA, 119-127.

1993

LARSEN L.O., DUFOUR S., 1993 - Growth, reproduction and death in lampreys and eels. in "Fish Ecophysiology", J.C. Rankin and Jensen F.B., Eds, Fish and Fisheries Series 9, Chapman and Hall, London, 72-104.

LECOMTE-FINIGER R., 1993 - Migration anadrome et caractères biomorphologiques des civelles de l'anguille européenne ( $A$. anguilla) dans le bassin occidental de la Méditerranée. Etat actuel des connaissances. Okeanos, 157-163.

1994

ELIE P., 1994 - Histoire d'une vie d'anguille - La vie de l'anguille dans les eaux continentales et son départ vers le grand large en direction de la mer des Sargasses. Le Pêcheur professionnel, 10, 17-20.

FEUNTEUN E., MARION L., 1994 - Impact of herons (Ardea cinerea) on fish communities: the case of the main european colony. Hydrobiologia, 279/280: 327-344.

GASCUEL D., FONTENELLE G., 1994 - Etude de la dynamique du stock d'anguilles dans un bassin versant en vue de sa gestion - Présentation d'une approche conceptuelle. in Coll. Franco-Québécois "Intégration des technologies modernes à la gestion des poissons dulcicoles et amphihalins", Cotton, Asselin, Shooner, Bernatchez, Berube (Ed.) Min. Env. et Faune du Québec - Service Faune aquatique, 210, 43-50.

LECOMTE-FINIGER R., 1994 - Les stades larvaires (leptocéphales et civelles) de l'anguille européenne (Anguilla anguilla, L.1758) : migrations et métamorphoses. Ann. Biol., 33, 1-17.

LECOMTE-FINIGER R., 1994 - The early life of the european eel. Nature (Scientific correspondence), vol. 370, p. 424.

\section{RAPPORTS TECHNIQUES}

1987

GASCUEL D., 1987 - La civelle d'anguille dans l'estuaire de la Sèvre Niortaise : biologie, écologie, exploitation. Publ. $n^{\circ} 4 / 1$ et $4 / 2$ Départ. Halieutique ENSA Rennes, $355 p$ et $205 p$.

1989

DEBENAY B., ELIE P., 1989 - Essais de mise en évidence de mortalités anormales de civelles d'Anguilla anguilla dans l'estuaire de la Gironde. Rapp. CEMAGREF/EDF/DRAF Aquitaine, $36 p+$ annexes. 
FEUNTEUN E., MARION L., ELIE P., RIGAUD C., 1989 - Prédation des hérons cendrés sur l'ichtyofaune des marais de l'Ouest - Etude du peuplement ichtyologique du marais endigué de Bourgneuf - Impact de la colonie de Grand-Lieu. Rap. CEMAGREF-Univ. Rennes-MNHN/SRETIE, $112 p$.

1991

GRELLIER P., HUET J., DESAUNAY Y., 1991 - Stades pigmentaires de la civelle d'Anguilla anguilla (L.) dan's les estuaires de la Loire et de la Vilaine. Rap. IFREMER-DRV, 91 14, RH/Nantes, $10 \mathrm{p}$.

GUERAULT D., DESAUNAY Y., BEILLOIS P., GRELLIER P., 1991 - Etude des montées tardives de civelles et des conditions de colonisation des bassins versants de Loire et de Vilaine (février à juin 90). Rap. IFREMER DRV/OCEHAL, $18 p$.

LECOMTE R., 1991 - L'anguille, grand migrateur à biologie énigmatique - Travaux du Laboratoire de Biologie Marine. Rap. Univ. Perpignan, $23 p$.

\section{Communications}

1987

DESAUNAY Y., GUERAULT D., BEILLOIS P., 1987 - Dynamique de la migration anadrome de la civelle ( $A$. anguilla) dans l'estuaire de la Loire : rôle des facteurs climatiques vis à vis de la pêche et du recrutement. Rap. CIEM, Comité «Poissons Anadromes et Catadromes", $M: 18,22 p$.

DESAUNAY. Y., GUERAULT D., GASCUEL D., 1987 - On the use of available data for an estimate of glass-eel recruitment. Working Party on Eel - EIFAC - Bristol 1987.

GASCUEL D., 1987 - Captures, cpue, abondance et dynamique de migration des civelles dans l'estuaire de la Sèvre Niortaise. Working Party on Eel - EIFAC - Bristol 1987.

\section{9}

PANFILI J., XIMENES M.C., DO CHI T., MIRALLES A., 1989 - Age determination of eels in the French mediterranean lagoons using classical methods and an image analysis system. Working Party on Eel - EIFAC - Porto (Portugal), $10 \mathrm{p}$.

1991

FONTENELLE G., 1991 - Age and growth of eel (Anguilla anguilla) on an european scale: a critical review. Working Party on Eel - EIFAC - Porto (Portugal), 31 p.

LECOMTE-FINIGER R., 1991 - Une méthode d'inclusion rapide des otolithes à l'aide d'une résine autopolymérisante à froid. Coll. "Tissus durs et âge individuel des vertébrés", INRANORSTOM, Bondy (France), 1991.

1993

DESAUNAY Y., GUERAULT D., LECOMTE-FINIGER R., 1993 - Variation of the oceanic larval migration of Anguilla anguilla glass eels from a two-year study in the Vilaine estuary (France). Working Party on Eel - EIFAC - Olsztyn (Pologne), 1994, 17 p.

DESAUNAY Y., LECOMTE-FINIGER R., GUERAULT D., 1993 - Mean age and migration patterns of Anguilla anguiulla glass eels from three french estuaries (Somme, Vilaine, Adour). Working Party on Eel, EIFAC - Olsztyn (Pologne), 1994, 7 p.

LECOMTE-FINIGER R., DESAUNAY Y., GUERAULT D., GRELLIER P., 1993 - The immigration of Anguilla anguilla glass eels in coastal waters. Questions about the determinism of the otolith structures. Working Party on Eel, EIFAC - Olsztyn (Pologne), 1994, $9 p$.

LECOMTE-FINIGER R., DESAUNAY Y., GUERAULT D., GRELLIER P., 1993 - Biometric features and age of glass eels (Anguilla anguilla) ascending the Vilaine estuary (France). Congrès "Fish otolith research and application", Hilton Head Island / USA, (poster), $11 \mathrm{p}$. 
LEGAULT A., 1993 - Preliminary study of the fluvial recruitment of eels. Working Party on Eel, EIFAC - Olsztyn (Pologne), 1993.

1994

GUERAULT D., DESAUNAY Y., LECOMTE-FINIGER R., 1994 - Biometry and otolithometry of Anguilla anguilla (L.) glass eels: towards a model for seasonal variation? Working Party on Eel, EIFAC, Oviedo (Espagne), 1994, 20 p.

\section{THESES ET DDI}

1987

MALLAWA A., 1987 - Dynamique des stocks exploités et halieutique de l'anguille européenne ( $A$. anguilla $L$.) des lagunes du Narbonnais et du Roussillon (BagesSigean et Canet-St Nazaire), Golfe du Lion. Thèse 3e cycle, Univ. Perpignan, $406 \mathrm{p}$.

1992

MOUNAIX B., 1992 - Intercalibration et validation des méthodes d'estimation de l'âge de l'anguille européenne (Anguilla anguilla) - Application au bassin versant de la Vilaine, Bretagne. DDI ENSA Rennes «Biol. Halieutique» - Publ. Dép. Halieutique, 14, $146 p$ + annexes.

1993

PANFILI J., 1993 - Estimation de l'âge individuel des poissons : méthodologies et applications à des populations naturelles tropicales et tempérées. Thèse $3 \dot{e}$ cycle Univ. Montpellier (U.S.T.L.) - Publi. "ORSTOM Editions», TDM, 112, 456 p. + annexes.

\section{4}

FEUNTEUN E., 1994 - Le peuplement piscicole du marais littoral endigué de BourgneufMachecoul (Loire-Atlantique) - Approche méthodologique pour une analyse quantitative de la distribution spatiale du peuplement et de la dynamique de certaines de ses populations. Thèse Univ. Rennes / CEMAGREF, $236 p$. + annexes. 


\section{PHYSIOLOGIE}

\section{Publications}

1987

COUNIS R., DUFOUR S., RIBOT G., QUERAT B., FONTAINE Y.A., JUTISZ M., 1987 Estradiol has inverse effects on pituitary glycoprotein hormone "Alpha" - subunit messenger ribonucleic acid in the immature european eel and the gonadectomized rat. Endocrinol., 121 (3), 1178-1184.

KHAN 1.A., LOPEZ E., LELOUP-HATEY J., 1987 - Induction of spermatogenesis and spermiation by a single injection of human chorionic gonadotropin in intact and hypophysectomized immature european eel ( $A$. anguilla). Gen. Comp. Endocrinol., 68 (1), 91-103.

LE BELLE N., FONTAINE M., 1987 - Les anguilles mâles et femelles peuvent-elles frayer une seconde fois dans la nature ? Ichtyophysiol. Acta., 11, 7-11.

SALMON C., MIYASHITA Y., MARCHELIDON J., FONTAINE Y.A., 1987 - Mise en évidence et propriétés des sites de liaison spécifique pour la gonadotropine de carpe dans des préparations membranaires d'ovaire d'anguille (Anguilla L.). Gen. Comp. Endocrinol., 65 (2), 203-211.

SEBERT P., BARTHELEMY L., CAROFF J., HOURNANT A., 1987 - Effects of hydrostatic pressure per se (101 ATA) on energetic processes in fish. Comp. Biochem. Physiol., A - Comp. Physiol., 86 (3), 491-495.

SIMONNEAUX V., BARRA J.A., HUMBERT W., KIRSCH R., 1987 - The role of mucus in ion absorption by the oesophagus of the sea-water eel ( $A$. anguilla L.) Electrophysiological, structural and cytochemical investigations. J. Comp. Physiol., B. Biochem. syst. environ. physiol., 157 (2), 187-199.

SIMMONEAUX V., HUMBERT W., KIRSCH R., 1987 - Mucus and intestinal ion exchanges in the sea-water adapted eel, Anguilla anguilla. J. Comp. Physiol. B. - Biochem. Syst. environ. Physiol., 157 (3), 295-306.

1988

DUFOUR S., LOPEZ E., LE MENN F., LE BELLE N., BALOCHE S., FONTAINE Y.A., 1988 Stimulation of gonadotropin release and of ovarian development by the administration of a gonadoliberin agonist and of dopamine antagonits in female silver eel preteated with estradiol. Gen. Comp. Endocrinol., 70 (1), 20-30.

LE BELLE N., DUFOUR S., MARQUET G., KERDELHUE B., FONTAINE Y.A., 1988 - Etat sexuel et axe gonadotrope hypothalamo-hypophysaire chez les 3 espèces d'anguilles de Tahiti (A. marmorata, A. megastoma, A. obscura). Bull. Mus. Natl. Hist. Nat., Sect. A, 10 (1), 147-160.

OLIVEREAU M., MOONS L., OLIVEREAU J., VAN DESANDE F., 1988 - Coexistence of corticotropin-releasing factor-like immunoreactivity and vasotocin in perikarya of the preoptic nucleus in the eel. Gen. Comp. Endocrinol., $70(1), 41-48$.

PENNEC J.P., LE BRAS Y.M., 1988 - Diel and seasonal rhythmus of the heart rate in the common eel (A. anguilla) : role of cardiac innervation. Expo. Biol., 47 (3), 155-160.

PENNEC J.P., WARDLE C.S., HARPER A.A., Mc DONALD A.G., 1988 - Effects of high hydrosttatic pressure on the isolated hearts of shallow water and deep sea fish. Results of Challenger cruise 6B/85. Comp. Biochem. Physiol. A - Comp. Physiol., 89 (2), 215-218. 
PIGAULT C., GERARD D., 1988 - Photolysis of the single trytophan residue of eel troponin C. Photochemistry and Photobiology, 48 (3), 349-351.

SAGLIO P., FAUCONNEAU B., 1988 - Free amino-acid content in the skin mucus of yellow and silver eel, Anguilla anguilla L. Comp. Biochem. Physiol., A - Comp. Physiol.

SALMON C., NUNEZ-RODRIGUEZ J., MARCHELIDON J., LE MENN F., FONTAINE Y.A., 1988 - Gonadotropia binding sites in eel ovary : autoradiographic visualization and new data on specificity. Reprod. Nutrit. Devel., 28 (4), 1165-1175.

SEBERT P., BARTHELLEMY L., CAROFF J., CANN-MOISAN C., 1988 - Effects of breatling an $\mathrm{O}_{(2)}-\mathrm{H}_{(2)}(20 \%-80 \%)$ mixture on the energy metabolism of the eel at 1 ATA. Aviat. Space. Envir. Med., 59 (8), 754-757.

SIMONNEAUX V., HUMBERT W., KIRSCH R., 1988 - Structure and osmoregulatory functions of the instestinal folds in the sea water eel, A. anguilla. J. Comp. Physiol., $B$ - Biochem. syst. environ. physiol., 158 (1), 45-55.

SOULIER P., PEYRAUD-WAITZENEGGER M., PEYRAUD C., BARTHELEMY L., 1988 - A study of barosensitivity in the european eel ( $A$. anguilla L.) : effects of arterial pressure changes on heart rate and ventilation. Exp. Biol., 47 (4), 243-250.

1989

DE LUZE A., LELOUP J., PAPKOFF N., KIKUYAMA S., KAWAUCHI N., 1989 - Effect of vertebrate prolactins and growth hormones on thyroxine 5 ' monodéiodination in the eel (Anguilla anguilla). A potential bioassay for growth hormone. Gen. Comp. Endocrinol., 73, 186-193.

DUFOUR S., LE BELLE N., BALOCHE S., FONTAINE Y.A., 1989 - Positive feedback control by the gonads on gonadotropin $(\mathrm{GTH})$ and gonadoliberin $(\mathrm{GnRH})$ levels in experimentally matured female silver eels ( $A$. anguilla). Fish Physiol. Biochem., 7 (1/4), 157-162.

HUMBERT W., VOEGEL J.C., KIRSCH R., SIMMONEAUX V., 1989 - Role of intestinal mucus in crystal biogenesis : an electron - microscopical, diffraction and $X$ ray microanalystical study. Cell. Tissue. Res., 255 (3), 575-583.

KAH O., DUFOUR S., BALOCHE S., BRETON B., 1989 - The GnRH systems in the brain and pituitary of normal and hCG treated European silver eels. Fish Physiol. Biochem., 6, (5), 279-284.

LEBEL J.M., LELOUP J., 1989 - Triiodothyronine binding to putative solubilized nuclear thyroïd hormone receptor in liver and gill of the brown trout (Salmo trutta) and the european eel (Anguilla anguilla). Gen. Comp. Endocrinol., 75, 301-309.

MILET C., MARTELLY E., LOPEZ E., 1989 - Purification of the parathyrin from the corpuscules of Stannius (PCS) of the eel (Anguilla anguilla L.). Gen. Comp. Endocrinol., 76, 83-94.

NAON R., MAYER-GOSTAN N., 1989 - Ca 2+ - stimulated ATPase activities in the gill of the eel : interactions of MG2+ - ions. Amer. Jl. Physiol., Regul. Integ. Comp. Phys., 25 (2), R313-R322.

SIMON B., SEBERT P., BARTHELEMY L., 1989 - Opposition des effets de la pression hydrostatique et de la pression partielle d'azote chez l'anguille. Med. subhyp., 8 (2), 77-93.

SIMON B., SEBERT P., BARTHELEMY L., 1989 - Effects of long term exposure to hydrostatic pressure per se (101 ATA) on eel metabolism. Can. Jl. Phys. Pharma, 67 (10), 1247-1251. 
1990

CHANOINE C., SAADI A., GUYOT-LENFANT M., HEBBRECHT C., GALLIEN C.L., 1990 Myosin structure in the eel ( $A$. anguilla L.) : demonstration of three heavy chains in adult lateral muscle. FEBS letters, 277 (1-2), 200-204.

KING J.A., DUFOUR S., FONTAINE Y.A., MILLAR R.P., 1990 - Chromatographic and immunological evidence for mammalian $\mathrm{GnRH}$ and chicken $\mathrm{GnRH}$ II in eel (Anguilla anguilla) brain and pituitary. Peptides, 11, 507-514.

LELOUP J., 1990 - Hormones thyroïdiennes et développement des poissons. Ichtyophysiol. Acta, 13, 115-122.

LOPEZ E., FONTAINE Y.A., LALLIER F., LE BELLE N., VIDAL B., 1990 - Stimulation hormonale, in vivo, de l'ovaire d'anguille européenne au stade jaune. Reprod. Nutrit. Devel., 30 (5), 577-582.

MEDINA M., LE BELLE N., REPERANT J., RIO J.P., WARD R., 1990 - An experimental study of the retinal projections of the european eel (Anguilla anguilla), carried out at the catadromic migratory, silver stage. Jl. für Inforschung, 31, 467-480.

OLIVEREAU M., OLIVEREAU J., 1990 - Effect of pharmalogical adrenalectomy on corticotroping-releasing factor-like and origine vasotocia immunoreactivities in the brain and pituitary of the eel : immunological study. Gen. Comp. endocrinol., 80 (2), 199-215.

OLIVEREAU M., OLIVEREAU J.M., 1990 - Corticotropin-like immunoreactivity in the brain and pituitary of three teleost species (goldfish, trout and eel). Cell. Tissue Research, 262 (1), 115-123.

QUERAT B., JUTISZ M., FONTAINE Y.A., COUNIS R., 1990 - Cloning and sequence analysis of the cDNA for the pituatary glycoprotein hormone subunit of the european eel. Mol. Cell. Endocrinol., 71, 253-259.

QUERAT B., MOUMNI M., JUTISZ M., FONTAINE Y.A., COUNIS R., 1990 - Molecular cloning and sequence analysis of the cDNA for the putative subunit of the type II gonadotrophin from the european eel. J. Mol. Endocrinol., 4, 257-264.

SEBERT P., BARTHELEMY L., SIMON B., 1990 - Laboratory system enabling long-terme exposure $(30 \mathrm{~d}$.) to hydrostatic pressure $(101 \mathrm{~atm})$ of fishes or other animals breathing water. Mar. Biol., 104 (1), 165-168.

1991

BURZAWA-GERARD E., DUMAS-VIDAL A., 1991 - Effects of 17 estradiol and carp gonadotropin on vitellogenesis in normal and hypophysectomized European silver female eel ( $A$. anguilla $L$.) employing a homologous radioimmunoassay for vitellegenia. Gen. Comp. endocrinol., 48 (2), 264-276.

MARCHELIDON J., BASSOMPIERRE M., MONTERO M., LE BELLE N., BALOCHE S., FONTAINE Y.A., 1991 - Stimulation of pituitary gonadotropic function in female silver eel treated by a gonadoliberin agonist and dopamine antagonist. in Scott A.P., SUMPTER J.P., KIME D.E., ROLFE M.S., Eds, Reproductive Physiology of fish, 54-56, Fish Symposium 91, Sheffield, Publ.

MARCHELIDON J., HUET J.C., SALMON C., PERNOLLET J.C., FONTAINE Y.A., 1991 - Purification et caractérisation des sous-unités présumées de l'hormone thyréotrope d'un poisson téléostéen, l'anguille (Anguilla anguilla). C.R. Acad. Sci., Série 3, $313(6), 253-258$.

MAYER-GOSTAN N., LEMAIRE S. 1991 - Measurements of fish gill ATPases using microplates. Comp. Biochem. Physiol. - B - Comp. Biochem., 98 (2-3), 323-326.

OLIVEREAU M., OLIVEREAU J., 1991 - Galanin-like immunoreactivity is increased in the brain of estradiol - and methyltestosterone - treated eels. Histochemistry, 96 (6), 487-497. 
OLIVEREAU M., OLIVEREAU J.M., 1991 - Corticotropin-like immunoreactivity in the brain of intact, hypophysectomised corticol - and metopirone - treated eels : comparison with changes in pituitary corticotropes and brain corticotropin - releasing factor. Cell. Tissue Research, 265 (3), 485-492.

QUERAT B., HARDY A., FONTAINE Y.A., 1991 - Regulation of the type II gonadotropin "Alpha" and $\beta$ subunit $n$ RNA s by oestradiol and testosterone in the european eel. J. Mol. Endocrin., 7 (1), 81-86.

SEBERT P., PEQUEUX A., SIMON B., BARTHELEMY L., 1991 - Effects of long-term exposure to 101-ATA hydrostatic pressure on blood, gill and muscle composition and on some enzyme activities on the freshwater eel (Anguilla anguilla). Comp. Biochem. Physiol., B - Comp. Biochem., 98 (4), 573-577.

1992

BURZAWA-GERARD E., DELEVALLEE-FORTIER B., 1992 - Implication de I'hormone de croissance au cours de l'induction expérimentale de la vitellogenèse par l'oestradiol $-17 \beta$ chez l'anguille femelle (Anguilla anguilla). C.R. Acad. Sci., Série 3, 314 (9), 411-416.

CHANOINE C., GUYOT-LENFANT M., EL ATTARI A., SAADI A., GALLIEN C.L., 1992 White muscle differentiation in the eel ( $A$. anguilla) : changes in the myosin isoforms pattern and ATP ase profile during post metamorphic development. Differentiation (London), 49 (2), 69-75.

SEBERT P., SIMON B., BARTHELEMY L., 1992 - Ethanol concentrations in plasma and tissues of fresh water eels ( $A$. anguilla) exposed to 101 ATA of hydrostatic pressure. Comp. Biochem. Physiol., A - Comp. Physiol., 101 (2), 233-235.

SIMON B., SEBERT P., CANN-MOISAN C., BARTHELEMY L., 1992 - Muscle energetics in yellow fresh water eels ( $A$. anguilla) exposed to high hydrostatic pressure (101 atm.) for 30 days. Comp. Biochem. Physiol., B - Comp. Biochem., 102 (2), 205-208.

1993

PEYON P., BALOCHE S., BURZAWA-GERARD E., 1993 - Synthesis of vitellogenia by eel (A. anguilla) hepatocytes in primary culture : requirement of 17 de la thyrotropine d'un poisson téléostéen, l'anguille(Anguilla anguilla). C.R. Acad. Sci. Sér. 3, 316 (8), 749-753.

DUFOUR S., MONTERO M., LE BELLE N., BASSOMPIERRE M., KING J.A., MILLAR R.P., PETER R.E., FONTAINE Y.A., 1993 - Differential distribution and response to experimental sexual maturation of two forms of brain gonadotropin-releasing hormone $(\mathrm{GnRH})$ in the european eel, Anguilla anguilla. Fish Physiol. Biochem., 11, 99-106.

SEBERT P., SIMON B., BARTHELEMY L., 1993 - Hydrostatic pressure induces a state resembling histototix hypoxia in Anguilla anguilla. Comp. Biochem. Physiol., A - Comp. Physiol. , 105 (2), 255-258.

1994

MEDINA M., REPERANT J., DUFOUR S., WARD R., LE BELLE N., MICELI D., 1994 - The distribution of GABA-immunoreactive neurons in the brain of the silver eel (Anguilla anguilla). Anat. Embryol., 189, 25-39.

MONTERO M., VIDAL B., KING J.A., VANDESANDE F., DUFOUR S., KAH O., 1994 Immunocytochemeical localization of mammalian GnRH (gonadotropin-releasing hormone) and chicken $\mathrm{GnRH}-\mathrm{Il}$ in the brain of the european silver eel (Anguilla anguilla L.). J. Chem. Neuroanat., 7, 227-241.

QUERAT B., CARDINAUD B., HARDY A., VIDAL B., D'ANGELO G., 1994 - Sequence and regulation of European eel prolactin mRNA. Mol. Cell. Endocrinol., 102, 151-160. 


\section{DOCUMENTS UNIVERSITAIRES (THESES ET DDI)}

\section{0}

NAON R., 1990 - Méthode de séparation des populations cellulaires de la branchie et activités ATPasiques cation-dépendantes dans les membranes plasmatiques de l'épithélium branchial chez l'anguille d'eau douce ( $A$. anguilla). Effet du calcium présent dans le milieu d'adaptation. DDI - Univ. Aix-Marseille 2.

SOULIER P., 1990 - Contribution à l'étude de la physiologie respiratoire et cardiovasculaire de l'anguille ( $A$. anguilla). Thèse $3 e$ cycle Univ. Brest.

1991

DEPOID-BAILLY DU BOIS M., 1991 - Action du cortisol et de la vitamine D sur le cartilage de croissance et métabolisme de la vitamine $D$ - Etude chez un mammifère (le lapin) et un poisson téléostéen (l'anguille). Thèse 3e cycle, Univ. Paris VI, $200 \mathrm{p}$. + annexes.

1992

OADY M.P., 1992 - Etude du polymorphisme de la myosine et des parvalbumines au cours de la croissance chez le saumon atlantique (S. salar) et chez l'anguille européenne (A. anguilla). Thèse $3 e$ cycle. Univ. Rennes I.

\section{4}

MESSAOURI-DEBOUN H., 1994 - Les récepteurs hépatiques de l'oestradiol chez l'anguille (Anguilla anguilla): caractérisation et rôle dans l'induction hormonale au cours de la vitellogénèse. Thèse $3 e$ cycle Univ. Paris VII / MNHN. 


\section{Dublications}

1987

AMIARD-TRIQUET C., AMIARD J.C., ANDERSEN A.C., ELIE P., METAYER C., 1987 The eel (Anguilla anguilla) as a bioindicator of metal pollution : factors limiting its use. Water Sci. Techn., 19 (7), 1229-1232.

BIAGANTI S., GONY S., LECOMTE R., 1987 - Etude de l'action toxique du cadmium sur des civelles (Anguilla anguilla). Rev. Int. Ocean. Med., t. LXXXV - LXXXVI, 1.

DUPONT F., GABRION C., 1987 - Dynamique de population de Bothriocephalus claviceps Goeze, 1782 (Cestoda pseudophyllidea), parasite de l'anguille (Anguilla anguilla) en Camargue. Vie et Milieu, 37 (2), 123-131.

DUPONT F., GABRION C., 1987 - The concept of specificity in the pro-cercoid-copepod system : Bothriocephalus claviceps (Cestoda), a parasite of the eel (A. anguilla). Parasit. Res., vol 73 (2), 151-158.

1988

DUPONT F., PETTER A.J., 1988 - Anguillicola, une épizootie plurispécifique en Europe : apparition de Anguillicola crassa (Nematoda, Anguillicolidae) chez l'anguille européenne $A$. anguilla en Camargue (sud de la France). Bull. Fr. Pêche Piscic., 308, 38-41.

GONY S., LECOMTE-FINIGER R., FAGUET D., BIAGANTI S., BRUSLE J., 1988 - Etude expérimentale de l'action du cadmium sur les juvéniles d'anguilles: biologie du développement et cytopathologie. Oceanis, vol. 14(1), 141-148.

1989

GONY S., 1989 - Etude préliminaire de la bioaccumulation du cadmium chez la civelle d'anguille (Anguilla anguilla). Bull. Soc. Zool. Fr., 114 (3), 162-166.

PETTER A.J., FONTAINE Y.A., LE BELLE N., 1989 - Etude du développement larvaire de Anguilla crassus (Dracunculoidea Nematoda) chez un cyclopidae de la région parisienne. Ann. Parasit. Hum. Comp., 64 (5), 347-355.

1990

BLANC G., MARCHAND A., GERARD J.P., 1990 - L'anguillicolose, un nouveau risque pour la filière anguille. Aqua Revue, 28, 27-32.

BRUSLE J., 1990 - Effects of heavy metals on eels, Anguilla sp. Aquat. Living Resour., 3, 131-141.

BRUSLE J., 1990 - Pathogenesis of the eel in culture. in "Pathology in Marine Science", Acad. Press. Inc., 441-454.

FONTAINE Y.A., LE BELLE N., LOPEZ E., QUERAT B., VIDAL B., BARTHELEMY L., SEBERT P., ALINAT J., PETTER A.J., 1990 - Infestation de populations françaises d'anguilles ( $A$. anguilla) par des nématodes (Anguilla crassus) : essais thérapeutiques et évaluation de risques potentiels liés à l'écophysiologie de l'hôte. Ann. Parasitol. Hum. Comp., 65 (2), 64-68.

LEMAIRE S., 1990 - Etude préliminaire de la bioaacumulation du cadmium chez la civelle d'Anguilla anguilla : distribution du métal dans l'organisme et décontamination, en eau douce et en eau saumâtre. C.R. Acad. Sci. Paris, 310, 625-630. 
LEMAIRE-GONY S., LEMAIRE P., MATHIEU A., 1990 - Etude de l'action conjuguée du cadmium et du benzo(a)pyrène sur le foie de l'anguille européenne. Rap. CIEM, $32(1)$.

PETTER A.J., CASSONE J., LE BELLE N., 1990 - Observations sur la biologie des premiers stades larvaires d'Anguillicola crassus, nématode parasite de l'anguille. Ann. Parasitol. Hum. Comp., 65, 28-31.

1991

BONNEAU S., BLANC G., PETTER A.J., 1991 - Etude sur la biologie des premiers stades larvaires d'Anguillicola crassus (Nematoda, Dracunculoidea). Spécificité de l'hôte intermédiaire et influence de la température sur la durée du développement. Bull. Fr. Pêche Piscic., 320, 1-6.

BRUSLE J., 1991 - The eel and organic chemical polluants in "The Science of the Total Environment". Elsevier Sci. Publ., 102, 1-19.

1992

BLANC G., BONNEAU S., BIAGANTI S., PETTER A.J., 1992 - Description of the larval stages of Anguillicola crassus (Nematoda, Dracuncoloidea) using light and scanning electron microscopy. Aquat. Living Resour., 5 (4), 307-318.

LEMAIRE-GONY S., LEMAIRE P., 1992 - Interactive effects of cadmium and benzo(a)pyrène on cellular structure and biotransformation enzymes of the liver of the european eel Anguilla anguilla. Aquatic Toxicology, 22 (2), 145-159.

VIVARES C.P., GRIMONT F., BAUDIN-LAURENCIN F., ANDRAL B., GRIMONT P.A., 1992 - Mocecular epidemiology of bacterial fish diseases : preliminary study with vibrio anguillarum. Aquaculture, 197 (2-3), 141-145.

1993

HASSAN BENAJIBA M., MARQUES A., BOUIX G., 1993 - Ultra structural data on the sporogenesis of Myxidium giardi, Cépède 1906 (Myxozoa, Myxosporidia), parasite of Anguilla anguilla (Teleostea). Europ. Jl. Protistology, 29 (2), 254-261.

\section{COMMUNICATIONS}

1987

BRUSLE J., 1987 - Eel and pollutants: a general review of the effects of heavy metals. Working Party on Eel, EIFAC, Bristol (Grande-Bretagne), 1987.

GONY S., 1987 - Experimental approach on the effects of cadmium on young yellow eels : an histological and SEM structural approach. Working Party on Eel, EIFAC, Bristol (Grande-Bretagne), 1987.

1989

GONY S., 1989 - Effects of cadmium on the gill of the european eel, Anguilla anguilla. Working Party on Eel, EIFAC, Porto (Portugal), 1989.

\section{DOCUMENTS UNIVERSITAIRES}

1989

BLANC G., 1989 - L'anguillicolose répartition géographique - Mise au point d'une méthode de diagnostic par échotomographie - Moyens de lutte. Thèse Vétérinaire - ENV Nantes.

1990

GONY-LEMAIRE S., 1990 - Etude expérimentale de l'action du cadmium sur les juvéniles (civelles et anguillettes) de l'anguille européenne (Anguilla anguilla) : analyse structurale et fonctionnelle de certains organes cibles. Thèse Univ. Paris VI. 
MIGRATIONS ET DEPLACEMENTS DANS LES EAUX CONTINENTALES

\section{Publications}

1988

LEGAULT A., 1988 - Le franchissement des barrages par l'escalade de l'anguille : étude en Sèvre Niortaise. Bull. Fr. Pêche Piscic., 308, 1-10.

1989

LARINIER M., DARTIGUELONGUE J., 1989 - La circulation des poissons migrateurs : le transit à travers les turbines des installations hydroélectriques. Bull. Fr. Pêche Piscic., 312/313, 1-90.

1990

LEGAULT A., FONTENELLE G., GASCUEL D., RIGAUD C., 1990 - Les passes à anguilles en Europe. Int. Rev. gesamt. Hydrobiol., 75/6, 843-844.

LEGAULT A., 1990 - Gestion des barrages estuariens et migration d'anguilles. Int. Rev. ges. Hydrobiol., 75/6, 819-825.

1992

ELIE P., 1992 - Histoire d'une vie d'anguille - La migration des civelles un marathon transformé en course d'obstacles par l'action de l'homme. Le Pêcheur Professionnel, 4, $2-4$.

LEGAULT A., 1992 - Etude de quelques facteurs de sélectivité de passes à anguilles. Bull. Fr. Pêche Piscic., 325, 83-91.

PORCHER J.P., 1992 - Les passes à anguilles -Gestion des ressources aquatiques. Bull. Fr. Pêche Piscic., 326-327, 134-142.

1994

LARINIER M., TRAVADE F., 1994 - Utilisation des dispositifs de franchissement pour le suivi des stocks et la gestion des populations de poissons migrateurs. in Coll. Franco-Québécois "Intégration des technologies modernes à la gestion des poissons dulcicoles et amphihalins» - Cotton, Asselin, Shooner, Bernatchez, Berube (Ed.), Min. Environ. et Faune du Québec, Service Faune aquatique, $210 p$.

\section{RAPPORTS TECHNIQUES}

1987

GASCUEL D., 1987 - La civelle d'anguille dans l'estuaire de la Sèvre Niortaise: biologie, écologie, exploitation. Publ. $n^{\circ} 4 / 1$ et 4/2 Départ. Halieutique ENSA Rennes, $355 p$ et $205 p$.

1988

RIGAUD C., FONTENELLE G., GASCUEL D., LEGAULT A., 1988 - Le franchissement des ouvrages hydrauliques par les anguilles (Anguilla anguilla) présentation des dispositifs installés en Europe. Publ. ENSA Rennes, Biol. Hal., 9, 16 p. + annexes.

ELIE P., DEBENAY B., 1992 - Premières estimations des quantités de civelles transitant dans le circuit de refroidissement de la centrale nucléaire du Blayais durant la saison de migration 1989 - 1990. Rap. CEMAGREF, $78 p$. 
Bull. Fr. Pêche Piscic. (1994) 335 : 297-317 - $312-$

LEGAULT A., FEUNTEUN E., 1992 - Etude de la migration estivale des anguilles au barrage de Golfech sur la Garonne. Rap. Fish Pass/Migado, 25 p.

1993

LEGAULT A., 1993 - L'anguille; Aménagement des obstacles à la migration. Pub. ADA $n^{\circ}$ 37. Fish-Pass / Min. Agriculture et Pêche, 33p.

\section{Communications}

1993

LEGAULT A., 1993 - Problems of eel migration in the management of estuarine dams. Working Party on Eel, EIFAC-Olsztyn (Pologne). 


\section{EXPLOITATION HALIEUTIQUE}

\section{Publications}

1990

GUERAULT D., DESAUNAY Y., 1990 - The glass eel (Anguilla anguilla) fishery in the Loire estuary in 1987 - Estimate of by-catches and their effects on resources. Int. Rev. Gesamt. Hydrobiol., 75 (6) (special issue), 837-839.

FONTENELLE G., GASCUEL D., MOUNAIX B., 1990 - Characteristics of an eel (Anguilla anguilla) fyke-net fishery within a small estuary (River Blavet, France). Int. Rev. Gesamt. Hydrobiol., 75 (6) (special issue), 797-806.

ROBIN J.P., 1990 - By-catch of juvenile flounder, Platichtys flesus L. 1758, in the glass eel fishery of the Loire estuary, France. Aquat. Living. Resour., 3 (2), 75-83.

\section{2}

BACH P., LEGENDRE P., AMANIEU M., LASSERRE G., 1992 - Strategy of eel (Anguilla anguilla) exploitation in the Thau lagoon. Estuarine, Coastal and Shelf sciences, 35 (1), 55-73.

1994

ELIE P., ROCHARD E., BABIN D., 1994 - Acquisition de données de capture par pêche en vue de la gestion de populations de poissons - Contraintes et méthodes en fonction des objectifs, exemple de l'anguille. 29-42, in coll. Franco-Québécois "Intégration des technologies modernes à la gestion des poissons dulcicoles et amphihalins", Cotton, Asselin, Shooner, Bernatchez, Berube (Ed.) Min. Env. et Faune du Québec Service Faune aquatique, $210 \mathrm{p}$.

\section{RAPPORTS TECHNIQUES}

\section{7}

AUBRUN L. 1987 - Inventaire de l'exploitation de l'anguille sur le littoral Sud-Gascogne. Publi. Dép. Halieut. ENSA Rennes, 5, $142 p$.

DESAUNAY Y., 1987 - Inventaire de l'exploitation de l'anguille sur le littoral Manche Est. Rap. IFREMER, DRV 087-018-RH Nantes, $36 p$.

\section{8}

CAVAILLES M., LOSTE C., 1988 - L'exploitation de l'anguille en Languedoc-Roussillon. Rap. CEPRALMAR, $114 p$.

ELIE P., BOIGONTIER B., ROCHARD E., 1988 - Etude du suivi halieutique de l'estuaire de la Gironde - 1987. Rap. CEMAGREF/EDF, $212 p$.

\section{9}

BABIN D., 1989 - Résultats de l'enquête expresse 1988. Etude socioéconomique de la pêche professionnelle continentale sur les bassins Seine, Loire-Allier, Vilaine pour l'année civile 88 (marins-pêcheurs exclus). Plaq. CEMAGREF Bordeaux/Equipe PMPC, 4 p.

ELIE P., ROCHARD E., BOIGONTIER B., 1989 - Etude de suivi halieutique de l'estuaire de la Gironde. Rapp. CEMAGREF/EDF, $196 p$. 
GUERAULT D., DESAUNAY Y., BEILLOIS P., GRELLIER P., ROBIN J.P., ROBINEAU B., 1989 - Les prises accessoires de la pêcherie de civelles (Anguilla anguilla) dans l'estuaire de la Loire en 1987. IFREMER Rap. Techn. DRV 089-030 - RH Nantes, $92 p$.

1990

CASTELNAUD G., BABIN D., 1990 - La pêche professionnelle aux filets et aux engins dans les eaux continentales françaises. $2^{e}$ partie : Rhône - Saône Doubs/Rhin/Somme/Charente/Garonne-Dordogne/Adour/Lacs Alpins. Rapp. CEMAGREF/Ministère Environnement, $141 p+$ annexes.

ELIE P., ROCHARD E., BOIGONTIER B., 1990 - Etude de suivi halieutique 89 de l'estuaire de la Gironde. Rapp. CEMAGREF/EDF/CPN Blayais, $170 \mathrm{p}$.

XIMENES M.C., LIEUTAUD A., 1990 - La production d'anguilles en lagunes de Méditerranée. Analyse et comparaison des sources statistiques. Résumé - Rap. CEMAGREF/SEM/Régions PACA et Corse.

1991

BABIN D., 1991 - Résultats de l'enquête expresse 1989 - Estimation de la production et du chiffre d'affaires des pêches professionnelles continentales françaises (marins pêcheurs exclus). Plaq. CEMAGREF Bordeaux - Eq. PMPC, 4 p.

CHANCEREL F., 1991 - L'anguille en Centre-Ouest : répartition de l'espèce et mode d'exploitation en zone continentale. Rap. Techn. CSP Poitiers, 13 p. + annexes.

SERTIER M., CASTELNAUD G., ROCHARD E., ELIE P., 1991 - Etude de suivi halieutique de l'estuaire de la Gironde en 1990. Rap. CEMAGREF, 261 p.

1992

CASTELNAUD G., BABIN D., 1992 - La pêche professionnelle fluviale et lacustre en France. Enquête au fil de l'eau. Coll. "Etudes», CEMAGREF, Série Ressources en eau $\mathrm{n}^{\circ} 5,289 \mathrm{p}$.

ELIE P., DEBENAY B., 1992 - Premières estimations des quantités de civelles transitant dans le circuit de refroidissement de la centrale nucléaire du Blayais durant la saison de migration 1989 - 1990. Rap. CEMAGREF, $78 p$.

SERTIER M., CASTELNAUD G., ROCHARD E., ELIE P., 1992 - Surveillance halieutique de l'estuaire de la Gironde en 1991. Rap. CEMAGREF, $162 p$.

1993

CASTELNAUD G., ROCHARD E., 1993 - Etude de surveillance halieutique de l'estuaire de la Gironde. Suivi statistique 1991 - Etude faune circulante 1992. Rap. CEMAGREF, $185 p$.

GUERAULT D., DESAUNAY Y., BEILLOIS P., 1993 - La pêche professionnielle des poissons migrateurs dans l'estuaire de la Loire en 1989. Rap. IFREMER/DRV, 93-009 $\mathrm{RH} / \mathrm{Nantes}, 23 \mathrm{p}$.

GUERAULT D., DESAUNAY Y., BEILLOIS P., 1993 - La pêche de l'anguille dans l'estuaire de la Loire en 1989. Rap. IFREMER/DRV, 93-029 - RH/Nantes, 28 p.

1994

GUERAULT D., DESAUNAY Y., BEILLOIS P., PROUZET P., MARTINET J.P., CUENDE F.X., 1994 - Les pêches professionnelles dans les estuaires de la Loire et de l'Adour "Repères Océan". IFREMER, $78 p$.

\section{Communications}

1987

CAVAILLES M., LOSTE C., 1987 - L'anguille, une ressource économique pour le LanguedocRoussillon (France). Working Party on Eel, Bristol (Grande-Bretagne), 1987. 
GUERAULT D., BEILLOIS P., DESAUNAY Y., 1987 - L'exploitation de la civelle (A. anguilla) en Loire et en Vilaine: indices d'abondance et indicateurs halieutiques. CIEM, Comité "Poissons Anadromes et Catadromes", M 19, $22 p$.

GUERAULT D., BEILLOIS P., DESAUNAY Y., 1987 - L'exploitation de la civelle (A. anguilla) en Loire et en Vilaine: indices d'abondance et indicateurs halieutiques. CIEM, Comité "Poissons Anadromes et Catadromes", M 19, $22 p$.

\section{8}

DESAUNAY Y., AUBRUN L., 1988 - Description des pêcheries d'anguilles (Anguilla anguilla) sur le littoral de la Manche et de l'Atlantique. CIEM, C.M. 1988 /M:25, $15 p$.

1989

FONTENELLE G., GASCUEL D., MOUNAIX-B., 1989 - Caractéristiques d'une pêcherie d'anguilles au verveux dans un petit estuaire (Blavet, France). Working Party on Eel, Porto (Portugal).

GASCUEL D., FONTENELLE :G., 1989 - Caractéristiques biologiques d'un peuplement estuarien d'anguilles sub-adultes (Estuaire de la Sèvre Niortaise - France). Working Party on Eel, EIFAC - Porto (Portugal), 1989, 12 p.

GUERAULT D., DESAUNAY Y., GRELLIER P., BEILLOIS P., 1989 - La pêcherie de civelles (Anguilla anguilla) en Loire en 1987. Evaluation des prises accessoires et impact halieutique. Working Party on Eel, EIFAC - Porto.(Portugal), 1989, 17 p.

GUERAULT D., DESAUNAY Y., 1989 -... Evolution de l'abondance de la civelle (Anguilla anguilla) dans les estuaires de la Loire et de la Vilaine (France) entre 1977 et 1988. Working Party on Eel, EIFAC - Porto (Portugal), 1989, 20 p.

GUERAULT D., DESAUNAY Y., GRELLIER P., BEILLOIS P.et ROBIN J.P., 1989 - Evaluation des prises accessoires de la pêcherie de civelles (Anguilla anguilla) en Loire (France). CIEM, CM 1989/M:13, $21 p$.

XIMENES M.C.; 1989 - Comparaison de deux indicateurs de l'effort de pêche dans les pêcheries lagunaires méditerranéennes d'anguilles. Working Party on Eel, EIFAC Porto (Portugal), 1989, $7 p$.

1991

GUERAULT D., PROUZET P., DESAUNAY Y.et BEILLOIS P., 1991 - The recent evolution of the glass eel immigration in three french atlantic estuaries. Working Party on Eel, EIFAC - Dublin, 1991, $18 p$.

\section{THESES}

1992

ROCHARD E., 1992 - Mise au point d'une méthode de suivi de l'abondance des amphihalins dans le système fluvio-estuarien de la Gironde, applicätion à l'étude écobiologique de l'esturgeon Acipenser sturio. Thèse $3 e$ cycle CEMAGREF/Univ. Rennes, 306 p. + annexes.

1993

BABIN D., 1993 - Contribution à l'étude d'une ressource naturelle renouvelable : la pêche professionnelle en eau douce en France. Thèse 3e cycle, CEMAGREF/Univ. Rennes.

SCHAAN O., 1993 - Exploitation d'un stock estuarien d'anguilles sub-adultes ( $A$. anguilla) Méthodes d'estimation des captures par âge. DDI-ENSA Rènnes, "Biol. Halieutique", $155 p+$ annexes. 


\section{AQUACULTURE}

\section{Publications}

1987

BRUSLE J., 1987 - Situation actuelle de l'anguilliculture : aspects techniques et biologiques. Oceanis, $13(1), 47-58$.

1990

GOUSSET B., 1990 - European eel (A. anguilla L.) farming technologies in Europe and in Japan : application of a comparative analysis. Aquaculture, 87 (3-4), 209-235.

YAHYAOUI A., BERRAHO A., LECOMTE-FINIGER R., 1990 - Comparison of growth rate of cultures elvers (Anguilla anguilla). Int. Rev. gesamt. Hydrobiol., 75 (6), 896.

1991

BILLARD R., 1991 - Elevage des anguilles au Japon. Aqua Revue, 34, $19-22$.

MOUTOUNET Y., PETIT J., 1991 - Estimation du potentiel d'une filière aquacole - Un exemple, l'anguilliculture - 1ère partie. Aqua Revue, 37, 9-14.

MOUTOUNET Y., PETIT J., 1991 - Estimation du potentiel d'une filière aquacole - Un exemple, l'angulliculture - 2e partie. Aqua Revue, 38, 37-41.

1992

ANONYME, 1992 - Facteurs déterminants de la croissance en aquaculture. Oceanis, 18 (1), 140 p. (Coll. Franco-Jap. Oceano, Nantes, 1991).

BERRAH A., YAHYAOUI A., LECOMTE-FINIGER R., AGUESSE P., 1992 - Comparaison des potentialités de croissance en élevage de civelles $(A$. anguilla) du littoral marocain - Variations géographiques et saisonnières - Influence d'un tri sélectif. Marine Life, 1 (1), 45-55.

GOUSSET B., 1992 - Eel culture in Japan. Bull. Inst. Oceanogr., Monaco, numéro spécial 10.

\section{COMMUNICATIONS}

1987

GOUSSET B., 1987 - Eel culture in Japan. Working Party on Eel, Bristol (GrandeBretagne).

THESES

1986

AFFANDI R., 1986 - Etude biologique de l'anguille ( $A$. anguilla) en élevage - Intérêt de l'ensilage acide dans l'alimentation. Thèse $3 e$ cycle Univ. Paris VI.

1990

VAN DE WIJDEVEN F., 1990 - L'anguilliculture intensive en France - Etat et perspectives. DDI - ENSA Rennes, «Biol. Halieutique», $172 p$. 
Bull. Fr. Pêche Piscic. (1994) 335 : 297-317 - $317-$

COMMERCIALISATION DE L'ANGUILLE

\section{RAPPORT TECHNIQUE}

1989

LEGRAND H., 1989 - Etude du marché de l'anguille. Publ. 19, Ass. Dévelop. Aquaculture, $86 p$. 